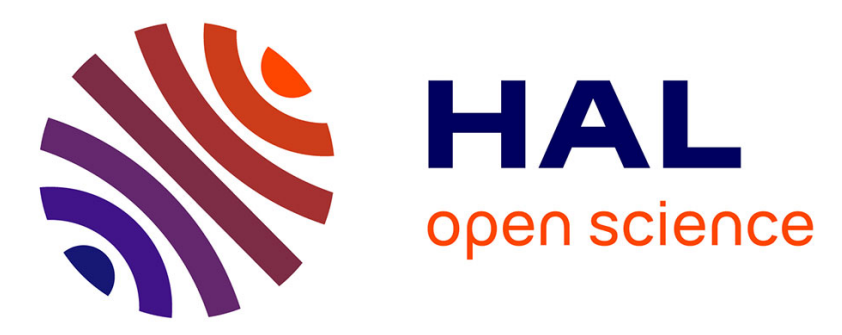

\title{
Variation in relative water content, proline accumulation and stress gene expression in two cowpea landraces under drought
}

Zahia Zegaoui, Séverine Planchais, Cécile Cabassa, Reda Djebbar, Ouzna

Abrous Belbachir, Pierre Carol

\section{To cite this version:}

Zahia Zegaoui, Séverine Planchais, Cécile Cabassa, Reda Djebbar, Ouzna Abrous Belbachir, et al.. Variation in relative water content, proline accumulation and stress gene expression in two cowpea landraces under drought. Journal of Plant Physiology, 2017, 218, pp.26-34. 10.1016/j.jplph.2017.07.009 . hal-01677429

\section{HAL Id: hal-01677429 \\ https: / hal.sorbonne-universite.fr/hal-01677429}

Submitted on 8 Jan 2018

HAL is a multi-disciplinary open access archive for the deposit and dissemination of scientific research documents, whether they are published or not. The documents may come from teaching and research institutions in France or abroad, or from public or private research centers.
L'archive ouverte pluridisciplinaire HAL, est destinée au dépôt et à la diffusion de documents scientifiques de niveau recherche, publiés ou non, émanant des établissements d'enseignement et de recherche français ou étrangers, des laboratoires publics ou privés. 
Variation in relative water content, proline accumulation and stress gene expression in two cowpea landraces under drought

Zahia Zegaoui ${ }^{1,2}$, Séverine Planchais ${ }^{1}$, Cécile Cabassa ${ }^{1}$, Reda Djebbar ${ }^{2}$, Ouzna Abrous Belbachir $^{2 *}$ and Pierre Carol ${ }^{1 *}$

${ }^{1}$ Sorbonne Universités, UPMC Univ Paris 06, iEES, UMR 7618, UPMC Paris 06 - Sorbonne (UPEC, UPMC, CNRS, IRD, INRA, Paris Diderot), case 237, 4 place Jussieu, F-75252 Paris cedex 05, France

${ }^{2}$ Laboratory of Biology and Physiology of Organisms, Faculty of Biological Sciences, Houari Boumediene University of Sciences and Technology, BP 32, El Alia 16111, Algeria

${ }^{*}$ Corresponding authors

\begin{abstract}
Many landraces of cowpea [Vigna unguiculata (L.) Walp.] are adapted to particular geographical and climatic conditions. Here we describe two landraces grown respectively in arid and temperate areas of Algeria and assess their physiological and molecular responses to drought stress. As expected, when deprived of water cowpea plants lose water over time with a gradual reduction in transpiration rate. The landraces differed in their relative water content (RWC) and whole plant transpiration rate. The landrace from Menia, an arid area, retained more water in adult leaves. Both landraces responded to drought stress at the molecular level by increasing expression of stress-related genes in aerial parts, including proline metabolism genes. Expression of gene(s) encoding proline synthesis enzyme P5CS was up regulated and gene expression of ProDH, a proline catabolism enzyme, was down regulated. Relatively low amounts of proline accumulated in adult leaves with slight differences between the two landraces. During drought stress the most apical part of plants stayed relatively turgid with a high RWC compared to distal parts that wilted. Expression of key stress genes was higher and more proline accumulated at the apex than in distal leaves indicating that cowpea has a non-uniform stress response at the whole plant level. Our study reveals a developmental control of water stress through preferential proline accumulation in the upper tier of the cowpea plant. We also conclude that cowpea landraces display
\end{abstract}


physiological adaptations to water stress suited to the arid and temperate climates in which they are cultivated.

Keywords: Cowpea, drought stress, proline, transpiration, gene expression

\section{Introduction}

Cowpea, the domesticated subspecies of Vigna unguiculata [Vigna unguiculata (L.) Walp.], is an important crop in semi-arid regions (Pasquet, 1993)(Pasquet, 1999)(Ba et al., 2004). Cowpea originates from the wild $V$. unguiculata spontanea and within the $V$. unguiculata subspecies, cultivated genotypes have been distinguished based on anatomical characteristics, and isozyme and DNA markers (Pasquet, 1993)(Pasquet, 1999)(Ba et al., 2004). Hundreds of cowpea genotypes currently cultivated worldwide are curated in seed banks (Egbadzor et al., 2014)(Ba et al., 2004).

African cowpea landrace diversity has been assessed using anatomical and developmental characteristics and molecular genotyping (Egbadzor et al., 2014)(Ghalmi et al., 2009). Genetically close African cowpea landraces (20 Algerian or 113 Ghana) often have similar features including seed-coat colour, ranging from black to red, mottled or cream (Egbadzor et al., 2014)(Ghalmi et al., 2010). However, geographically and genetically distant landraces with different adaptations may have similar features, for example, by having the same seedcoat colour (Ghalmi et al., 2009)(Muchero et al., 2009)(Huynh et al., 2016).

Compared to other leguminous plants, cowpea is considered to be drought resistant (Belko et al., 2013). Yield, photosynthesis, water content, transpiration and water potential of local cowpea landraces have been compared showing that the ability to withstand drought varies according to the genotype (Singh et al., 2010; Singh and Raja Reddy, 2011). A subset of especially drought resistant cowpea landraces have been identified as possible progenitors for breeding improved cowpea varieties (Hall, 2012).

When cowpea responds to drought stress stomata close rapidly and leaf transpiration is reduced (Hall and Schulze, 1980)(Belko et al., 2013). ABA and lipid signalling and lipid enzyme activity have been correlated to stomatal closure and drought resistance in cowpea (Iuchi et al., 2000)(Torres-Franklin et al., 2007)(Singh and Raja Reddy, 2011). Stress and ABA also induce the expression of stress-related transcription factors, such as DREB2A, which in turn induce a variety of stress-responsive genes (Sadhukhan et al., 2014a). 
During water stress, plant mitochondria and chloroplasts accumulate reactive oxygen species (ROS) as by-products of respiration and photosynthesis respectively (Mittler, 2002). A variety of enzymatic or non-enzymatic mechanisms or the induction of alternative electron transport may limit the amount of ROS that accumulates during stress. For example, mitochondrial alternative oxidase (AOX) isoforms can be induced by drought in plants, including cowpea, to limit mitochondrial ROS production (Vanlerberghe et al., 2016)(Costa et al., 2010)(Wang and Vanlerberghe, 2013). The plastid terminal oxidase PTOX, a chloroplast homologue of AOX, is induced in some plant species to limit excess electron transfer in the chloroplast during stress (Laureau et al., 2013) (Johnson and Stepien, 2016).

Another characteristic of stress response in plants is the synthesis of osmolytes, small molecules, such as sugar and the amino acid proline (Szabados and Savouré, 2010). These molecules allow dehydrated plant cells to withstand dehydration by maintaining turgor, buffering against ROS and maintaining redox homeostasis (Szabados and Savouré, 2010). Proline accumulates when it is synthesised from glutamate at the same time as its catabolism is repressed. Drought stress induces expression of the biosynthetic gene P5CS, which encodes bi-functional pyrroline-5-carboxylate synthase (EC 2.7.2.11/1.2.1.41) (PérezArellano et al., 2010), and represses ProDH, which encodes proline dehydrogenase (EC 1.5.5.2) (Peng et al., 1996) (Verslues and Sharma, 2010). Different signals induce proline biosynthesis in plants. ABA signalling induces P5CS (Savouré et al., 1997)(Strizhov et al., 1997) and lipid signalling, through the action of phosphatidic acid and ROS produced by NADPH oxidases, can modulate P5CS and ProDH gene expression (Ghars et al., 2012)(Ben Rejeb et al., 2015).

To better characterise cowpea adaptation, we measured variations of key physiological indicators and gene expression in response to drought stress in two cowpea landraces originating from regions of Algeria with either temperate or arid climates. Relative water content (RWC) was measured to better characterize water deficit. The landrace originating from the arid area maintained a higher RWC over the duration of the drought stress and transpired less than the landrace from the temperate area. In both landraces, proline biosynthesis genes are regulated by drought stress but surprisingly, more proline accumulates in the upper tier of the plant compared to older leaves suggesting developmental control of water stress responses. 


\section{Materials and methods}

\section{Plant material and growth}

Cowpea [Vigna unguiculata (L.) Walp.] landraces were provided by local Algerian farmers. Landrace Bejaia (named B in this work) is grown in Bejaia in north-east Algeria, an area with a sub-humid climate. Landrace Menia (named $\mathrm{M}$ in this work) is grown in Menia in central Algeria, a relatively hot and arid region (according to Emberger classification) (Emberger, 1955) (Peel et al., 2007) (Table 1).

Seeds of landrace Bejaia (B) are black, while seeds from landrace Menia (M) are pale or deep golden in colour (Supp. Fig. 1A). The mean 100-seed weight is $7.06 \mathrm{~g}$ for Landrace B and $6.91 \mathrm{~g}$ for landrace $\mathrm{M}$ ( $\mathrm{p}<0.001$ using a Mann-Whitney test with $\mathrm{n}=10$ samples) (Supp. Fig.1B).

Seeds were surface sterilized, imbibed on moist filter paper overnight at $4^{\circ} \mathrm{C}$, and left to germinate at room temperature. Germinated seeds were transplanted into $1800 \mathrm{~cm}^{3}$ plastic containers containing $60 \mathrm{~g}$ of a peat-perlite-vermiculite mixture $(2: 1: 1, \mathrm{v} / \mathrm{v} / \mathrm{v})$. The peat (reference V1 mix, Jiffy Products International BV, The Netherlands) is a mix of white and black peat with added fertilizer NFU42001 giving NPK content of 17, 10 and $4 \mathrm{~kg} / \mathrm{m}^{3}$ respectively.

Plants were grown at $22^{\circ} \mathrm{C}$ in long-day conditions (16h light) in a temperate glasshouse under natural light supplemented with sodium lamps with photosynthetically active radiation (PAR) averaging $90 \mu$ moles photons $\mathrm{m}^{-2} \mathrm{~s}^{-1}$. Total PAR was estimated between 90 to 500 $\mu$ moles photons $\mathrm{m}^{-2} \mathrm{~s}^{-1}$, a makeshift shutter system cutting-off excess light.

\section{Imposition of drought stress, measuring relative water content and transpiration}

Prior to drought the experiment, plants were grown for seven days until the first trifoliate leaves (TFL1) had fully developed, at which time a watering of the soil to saturation was conducted. To impose drought stress, watering was stopped. Relative water content (RWC) was determined for TFL1 or for the upper tier of plants (youngest emerging leaf and apical bud) as stated. The organs were first weighed to determine the fresh weight (FW) then weighed again to determine the turgid weight (TW) after they had been fully hydrated in deionised water for 1 day at $4{ }^{\circ} \mathrm{C}$ in the dark. The organs were then dried for 2 to 4 days in an oven at $70^{\circ} \mathrm{C}$ and weighed again to determine the dry weight (DW). RWC was calculated as $100 \times(\mathrm{FW}-\mathrm{DW}) /(\mathrm{TW}-\mathrm{DW})$. Leaf transpiration was measured using a customised computer-linked weighing machine. After detaching a leaf, the cut petiole was sealed with 
grease, and weight loss ascribed to transpiration was recorded for 140 to 180 minutes. Whole plant transpiration was estimated by recording whole plant weight loss after masking the soil surface with plastic film to limit evaporation.

To measure the humidity of the soil, soil was collected from plant pots and weighed (FW). The soil was fully hydrated by soaking it in water then allowing it to drip for 24 hours before weighing (SW). Then the soil was baked to dry it and weighed again (DW). The relative humidity was calculated as a percentage of the fully hydrated soil weight as $100 \times$ (FW-DW)/SW.

\section{Molecular biology \\ RNA extraction}

For each sample, $100 \mathrm{mg}$ of leaves were homogenized in RNA extraction buffer $(0.2 \mathrm{M}$ Tris-HCl pH 7.5, 0.25 M NaCl, $25 \mathrm{mM}$ EDTA, 0.5\% SDS) and mixed with an equal volume of citrate-buffered $(\mathrm{pH} 4)$ phenol-chloroform $(1: 1, \mathrm{v} / \mathrm{v})$. Samples were centrifuged at 10000 rpm for $5 \mathrm{~min}$. The upper aqueous phase was removed and re-extracted with the phenolchloroform mix. RNA was selectively precipitated from the aqueous phase with $2 \mathrm{M} \mathrm{LiCl}$ at $0^{\circ} \mathrm{C}$ overnight. RNA was pelleted by centrifugation at $12000 \mathrm{rpm}$ for $15 \mathrm{~min}$ and dissolved in water. A second precipitation of RNA with $2 \mathrm{M} \mathrm{LiCl}$ was done for $6 \mathrm{~h}$ at $0^{\circ} \mathrm{C}$. After centrifugation, RNA pellets were washed with $70 \%$ ethanol, dried and dissolved in $50 \mu \mathrm{L}$ water. RNA was quantified by measuring UV absorbance at 260 and $280 \mathrm{~nm}$ using a Nanovue spectrophotometer. After DNase treatment, RNA integrity was checked by electrophoresis on a $1 \%$ agarose gel.

\section{Semi-quantitative RT-PCR}

For reverse transcription $1.5 \mu \mathrm{g}$ of RNA was used with Revert Aid Reverse Transcriptase according to the manufacturer's instructions (Thermo Scientific). Complementary DNA samples were diluted 4 fold with ultrapure water. PCR was done using Dream Taq Green DNA polymerase (Thermo Scientific). For each PCR reaction, $2 \mu \mathrm{L}$ of cDNA was used as a template, $0.8 \mu \mathrm{M}$ of both forward and reverse primers, $0.2 \mathrm{mM}$ dNTP and 1 unit of DreamTaq in $1 \times$ GreenTaq Buffer. PCR conditions were: 5 min at $94^{\circ} \mathrm{C}$, followed by 28 cycles of $30 \mathrm{~s}$ at $94^{\circ} \mathrm{C}, 30 \mathrm{~s}$ at $55^{\circ} \mathrm{C}$ and $30 \mathrm{~s}$ at $72^{\circ} \mathrm{C}$, and finally $10 \mathrm{~min}$ at $72^{\circ} \mathrm{C}$. In these conditions, the amount of PCR product amplified allows semi-quantitative estimation of the level of expression of each gene tested compared to control gene expression.

\section{Oligonucleotide primer design}


Gene sequences were retrieved from the Genespace Sequence (GSS) database of the Cowpea Genomics Initiative (CGKB) (Chen et al. 2007) and from NCBI Genbank. The gene $\mathrm{VuEF1}$, whose expression remains steady during drought stress, was selected as a control. Oligonucleotide primers used for PCR experiments were designed specifically for this study using Primer3 software to have an annealing temperature of $55^{\circ} \mathrm{C}$ and amplify 200 to $400 \mathrm{bp}$ of cDNA sequence. Table 2 lists the primer sequences of the genes studied with the corresponding Genebank identification numbers and publication reference. Some primers were also designed and described in Y. Maia (2012).

\section{Proline and MDA quantification}

Proline content was determined by a colorimetric method adapted from Bates et al., 1973. Pulverized frozen tissue (20 to $50 \mathrm{mg}$ ) was homogenized in $0.75 \mathrm{~mL}$ of $3 \%$ sulfosalicylic acid. The homogenate was centrifuged at $14000 \mathrm{rpm}$ at $4^{\circ} \mathrm{C}$ for $10 \mathrm{~min}$. Ninhydrin buffer (2.5\% ninhydrin, $60 \%$ acetic acid in $2.5 \mathrm{M}$ phosphoric acid) and $100 \%$ acetic acid were added to $0.4 \mathrm{~mL}$ of supernatant $(1: 1: 1, \mathrm{v} / \mathrm{v} / \mathrm{v})$. The colour reaction was developed for $60 \mathrm{~min}$ at $95^{\circ} \mathrm{C}$. After cooling, $0.8 \mathrm{~mL}$ of toluene was added to each sample. The optical density of the upper organic phase was read at $520 \mathrm{~nm}$. Proline was quantified by comparison with Lproline as the standard. MDA was quantified using the thiobarbituric acid (TBA) colorimetric reaction according to Hodges et al. (1999). 


\section{Results}

\section{Dynamics of water loss are different in two cowpea landraces from Algeria}

Two cowpea landraces originating distant areas of Algeria, were expected to be genetically and physiologically adapted to their local climates or environments. Bejaia has a sub-humid climate, while Menia is an arid area (according to Emberger classification) (Emberger, 1955) (Peel et al., 2007) (see section 2.1, Table 1).

We wanted to test the molecular and physiological response of cowpea to progressive dehydration, which mimics natural drought conditions better than hyperosmotic stress, an can result in severe dehydration. The RWC of the first trifoliate leaves (TFL1) of each landrace was measured during two weeks of progressive dehydration. At the start, the RWC of both cowpea genotypes was above 95\% (Figure 1). After one week without water RWC lowers, however, landrace M had a higher RWC than B (Fig. 1A). This difference widened over time. For example, after $13 \mathrm{~d}$ landrace $\mathrm{M}$ had $72 \% \mathrm{RWC}$ compared to $57 \%$ for landrace B. The difference in TLF1 RWC was even greater after $15 \mathrm{~d}$ when landrace B had lost $30 \%$ more water than landrace M (Fig. 1A). The humidity of the soil was confirmed to be similar for both $\mathrm{M}$ and $\mathrm{B}$ samples, diminishing over time at a similar rate (Fig. 1B). We can therefore hypothesize that when subjected to water stress the landrace from the arid region is able to retain water more effectively than the landrace from a sub-humid area. However, RWC values at the end of the stress experiment are much lower than usually measured in field studies and might be unrepresentative of natural field conditions (Cruz de carvalho et al., 1998, Belko et al., 2013).

\section{Leaf and whole plant transpiration}

We investigated whether the difference in RWC between the cowpea landraces is related to leaf and whole plant transpiration. We measured water loss from detached TFL1 from M and B plants with similar RWC (Figure 2A-C). When plants are fully hydrated their transpiration rate is maximal with evaporation of $10 \mathrm{~g}$ of water in $1 \mathrm{~h}$ (Figure $2 \mathrm{~A}$ ). The transpiration rate was threefold less in leaves from partially dehydrated plants with RWC of $85-87 \%$ (Fig. 2B). Transpiration is ten times less than the maximum in plants with $76-78 \%$ RWC with $1 \mathrm{~g}$ of water lost per h (Fig. 2C). TFL1 transpiration rates for the two landraces were similar for plants with similar RWC. TFL1 area is slightly but not significantly different between landraces (Landrace Bejaia $39.25 \mathrm{~cm} 2$ +/- 5.15; landrace Menia 34.66 +/5.57). 
Plants had similar total leaf area $(73.5 \mathrm{~cm} 2$ for Bejaia and $76.26 \mathrm{~cm} 2$ for Menia) Whole plant transpiration was recorded in dehydrating plants. (Figure $3 \mathrm{~A}, \mathrm{~B}$ ). For $3 \mathrm{~d}$ after watering soil to saturation, transpiration increased to similar high rates for both landraces (Fig. 3A). After $7 \mathrm{~d}$ of water deprivation, daily transpiration is reduced by $80 \%$ (Fig. 3B). From this point, daily water loss was always higher for the B landrace (Fig. 3B). However, variations within samples were too large for this difference to be highly statistically significant ( $p>0.05$ using a Mann-Whitney test). While single leaf transpiration is similar in the two cowpea landraces the kinetics of whole plant transpiration could be slightly different.

Progressive drought triggers expression of stress-response and proline-synthesis genes but little proline accumulation

When plants undergo water stress, specific changes in expression of key genes occur that in turn modulate other genes to generate a physiological response (Shinozaki and YamaguchiShinozaki, 1997)(Bray, 2004). VuDREB2A, which encodes DREB2A transcription factor, and $V u N C E D 1$, which encodes NCED1 enzyme involved in ABA synthesis, have both been characterised in cowpea (Sadhukhan et al., 2014)(Iuchi et al., 2000). VuDREB2A and $V u N C E D 1$ mRNA levels increased as early as $7 \mathrm{~d}$ after the onset of water deprivation which corresponded to $88 \% \mathrm{RWC}$ for the $\mathrm{M}$ landrace and $82 \% \mathrm{RWC}$ for the $\mathrm{B}$ landrace. (Sadhukhan et al., 2014)(Iuchi et al., 2000) mRNA levels remained high during the second week of dehydration fluctuating slightly (Figure 4). We tested the effect of water stress on chloroplast and mitochondria electron transfer which can result in oxidative stress (Bartoli et al., 2005). Expression of the chloroplast PTOX gene is part of the stress response of some plant species (Johnson and Stepien, 2016)(Laureau et al., 2013). A low level of PTOX expression was detected in cowpea in control conditions (Fig. 4A). VuPTOX mRNA accumulated during water deprivation and remained at this higher level (Fig. 4A). Not all genes encoding chloroplast functions are up regulated. For example, expression of $V u R B C S$, encoding the Rubisco small subunit, did not vary (Fig. 4A). We also tested mitochondrial AOX expression. Some, but not all, AOX genes are up-regulated during stresses that induce mitochondrial dysfunction or during oxidative stress (Costa et al., 2010)(Vanlerberghe et al., 2016). In our experiment, $V u A O X 1$ and $2 b$ mRNA accumulation did not vary in either landrace (Fig. 4A). Malonyl dihadehyde (MDA), a marker of oxidative stress, resulting from lipid peroxidation (Hodges et al., 1999) was tested (Supplementary Figure 2). MDA increased $39 \%$ in landrace B and $75 \%$ in landrace $M$ after 15 days of drought suggesting a 
oxidative stress and a lipid peroxidation as a consequence of draught stress more pronounced in the B landrace (Supplementary Figure 2).

Proline metabolism genes are targets of stress regulation in cowpea (Shui et al., 2013). The P5CS gene encodes the enzyme responsible for the rate-limiting step of proline synthesis. We found that the proline biosynthesis VuP5CS mRNA was barely detectable in control conditions but it accumulated as early as $7 \mathrm{~d}$ after the start of dehydration (Fig. 4A). More VuP5CS mRNA accumulated as RWC decreased. However, even though RWC of the B landrace decreased more, the VuP5CS mRNA signal was not higher than in the M landrace (Fig. 4A). VuProDH mRNA encoding the proline catabolism enzyme ProDH was detected in cowpea in the control conditions but levels decreased during stress (Fig. 5A). After $7 \mathrm{~d}$ of water deprivation landrace $\mathrm{M}$ had higher $V u$ ProDH mRNA levels and higher RWC than landrace B (Fig. 4A).

As cowpea P5CS and ProDH were regulated by water stress at the gene expression level, proline synthesis could also have been up-regulated and proline catabolism down-regulated. To test this, we tried to correlate gene expression and proline accumulation in TFL1 in response to water stress. There was a lag of several days between induction of P5CS gene expression and the accumulation of measurable amounts of proline. Proline was barely detectable for $10 \mathrm{~d}$ after the onset of the water deprivation although VuP5CS mRNA had increased after $7 \mathrm{~d}$ (Fig. 4A-B). A difference in proline accumulation between landraces became noticeable after $13 \mathrm{~d}$. Landrace B accumulated up to $300 \mathrm{nmol}$ of proline per $\mathrm{g}$ of DW, 5 times more than landrace M (Fig. 4B), which also correlates with the difference in RWC between genotypes.

\section{Gene expressions and proline accumulation in younger leaves}

We observed that the upper tier of cowpea plants, including the apex and younger leaves, was more turgid than TFL1 after two weeks of dehydration (Supplementary Figure 3). RWC of upper tiers remained above $65 \%$ for the whole dehydration period in both landraces (Figure 5). We investigated the gene expression response to water stress in upper tiers (Fig. $5 \mathrm{~A})$. Both $V u D R E B 2 A$ and $V u P 5 C S$ were expressed in the absence of stress and upregulated as RWC decreased (Fig. 5A). VuProDH expression was down regulated upon stress. When plants were watered again after deprivation, VuP5CS and VuDREB2A levels decreased while $V u P R O D H$ levels increased. Stress and stress relief were therefore readily perceived by tissues at the apex, even though the variation in RWC was limited (Fig. 5A). 
Proline content of the upper tier was very low in the absence of stress (Fig. 5B). Proline content increased 20 to 30 fold with stress, reaching $45 \mu \mathrm{mol}$ per g of DW when RWC was the lowest after 2 weeks of dehydration. Both cowpea genotypes had accumulated similar amounts of proline at similar RWC. Most strikingly, more proline accumulated in the upper tier than in TFL1. From $0.306(\mu \mathrm{mol} / \mathrm{g}$, DW) proline in TFL1 to $49.6 \mu \mathrm{mol}$ proline in upper tier, proline is 100 times more abundant in landrace B upper tier compared to TFL1. Similarly, for landrace M, from 0.047 ( $\mu \mathrm{mol} / \mathrm{g}, \mathrm{DW}$ ) proline in TFL1 to 44.82 in upper tier, proline is 900 times more abundant in landrace $\mathrm{M}$ in upper tier compared to TFL1. (Fig. $5 B)$.

\section{Discussion}

\section{RWC variation and transpiration in cowpea}

Here we describe two cowpea landraces from Algeria. The landraces are easily distinguished by their different seed colours, which might be due to mutations in flavonoid biosynthesis genes occurring independently in local populations, as seen for example in the Glycine max (soybean) chalcone synthase gene (Todd and Vodkin, 1996)(Tuteja et al., 2009). Seed colour may indicate how closely related two landraces are but is not a sufficient marker of diversity on its own.

Cowpea plants regulate water loss according to whether they are well watered or subject to drought or vapour pressure deficiency (Hall and Schulze, 1980). The basis of this regulation has been ascribed to soil-root interaction and whole plant signalling rather than to a decline in leaf water potential (Osonubi, 1985). Landrace M, which originates from an area with an arid climate, maintained a higher RWC than landrace B over the two-week dehydration. Other comparisons of cultivated varieties or wild populations have shown that RWC can be used to distinguish between varieties that are tolerant or susceptible to drought. For example, comparison of RWC amongst drought tolerant and sensitive beans (Phaseolus vulgaris) allowed ecotypes to be distinguished (Rosales et al., 2011). In the model plant Arabidopsis, different ecotypes (or accessions) can be distinguished based on variation in RWC in response to mild drought. Plant populations adapted to arid climates can also be distinguished by direct measurement of RWC or indirectly by measuring the ratio of carbon isotope delta C13 (McKay et al., 2003). There is likely to be a range of physiological adaptations as RWC itself varies amongst Arabidopsis ecotypes in well-watered conditions 
and under drought (Bac-Molenaar et al., 2016). Midday RWC drop is a parameter that allows discrimination between some cowpea ecotypes (Kumar et al., 2008; Hayatu et al., 2014).

The two landraces had an almost identical RWC over the first week of drought stress. This is contrary to what has previously been observed in well-watered plants from arid and subhumid climates. Only after 8 days did RWC differ in landrace B and M. It is therefore possible that the landraces are both tolerant to mild drought stress, that can only be distinguished in terms of RWC after severe water shortage.

Transpiration was nearly identical in both landraces when well-watered. Our results show that leaf transpiration from isolated TFL1 varies when plants are subjected to drought. A threefold decrease in transpiration is observed after one week of stress when RWC is only moderately lower (85-87\% compared to $93 \%$ ), illustrating the tight regulation of cowpea transpiration by stomatal closure (Belko et al., 2013). Furthermore, in stressed plants with 76-78\% RWC, transpiration was tenfold less. RWC of landrace M remains higher for longer than in the B landrace so total transpiration from TFL1 is potentially greater in the M landrace, an apparently paradoxical observation. However, all transpiration rates are very low and TFL1 might not represent whole plant transpiration.

Whole plant transpiration of well-watered plants is mostly similar between landraces. In landrace $\mathrm{M}$, however, transpiration is slightly lower during drought. Several factors, such as $\mathrm{ABA}, \mathrm{CO}_{2}$ and redox status, contribute to stomata closure and transpiration regulation during drought (Kim et al., 2010)(Djebbar et al., 2012)(Singh and Raja Reddy, 2011). For example, in cowpea plants that were dehydrated for $10 \mathrm{~h}$ after uprooting, endogenous ABA increased 140 times in leaves (Iuchi et al., 1996)(Iuchi et al., 2000). Studying 40 cowpea genotypes, Belko et al. (2013) found that drought-sensitive genotypes had higher transpiration rates than drought-tolerant genotypes both in well-watered and vapour pressure deficit conditions (Belko et al., 2013). Natural variation in drought resistance in a related species, Vigna unguiculata sesquipedalis (asparagus bean), was also attributed to variation in transpiration rates in response to vapour pressure deficit and soil drought $(\mathrm{Xu}$ et al., 2015). An explanation for our results could be that transpiration physiology and other mechanisms might contribute to local adaptation. Five quantitative trait loci related to drought and senescence physiology have been identified by studying the natural variation in local cowpea landraces, including the "stay green" phenotype (Muchero et al., 2009)(Muchero et al., 2010). Similar quantitative loci were also identified in asparagus bean 
(Xu et al., 2015). Whole plant physiology mechanisms therefore contribute to plant droughtstress adaptation.

\section{Stress response revealed by gene expression}

Genes expressed in cowpea in response to drought stress include $V u D R E B 2 A$, whose gene product is similar to Arabidopsis DREB2A transcription factor that regulates other genes involved in the molecular stress response including ABA biosynthetic genes (Sadhukhan et al., 2014a)(Sadhukhan et al., 2014b). VuDREB2A and VuNCED1 expression were previously found to be induced $6 \mathrm{~h}$ after the onset of dehydration and prior to ABA accumulation in stems and leaves, but not in roots (Iuchi et al., 2000)(Sadhukhan et al., 2014a). We found $V u N C E D 1$ expression increased in both landraces during drought stress with a stronger signal in landrace $B$ after $13 \mathrm{~d}$. The latter observation could be a consequence of landrace B having a lower RWC at this stage. Although the results suggest that cowpea responds to dehydration by modulating ABA synthesis, the stronger expression of $V u N C E D 1$ in landrace B did not lead to better control of transpiration.

Membrane lipid metabolism and antioxidant genes are induced by drought stress in cowpea (Torres-Franklin et al., 2007, 2008). Stress-regulation of mitochondrial AOX is well documented (Bartoli et al., 2005)(Vanlerberghe et al., 2016). In cowpea seedlings, VuAOX genes 1 and 2b (Costa et al., 2007)(Costa et al., 2010) are transiently expressed and AOX activity increases under short severe drought stress (Costa et al., 2010). In the two landraces studied here, the two VuAOX mRNA tested were not up-regulated after days of progressive dehydration. It is possible that AOX is activated at the protein level though (Umbach et al., 2006).

Chloroplast PTOX resembles AOX (Carol et al., 1999)(Carol and Kuntz, 2001) and is associated with carotenoid synthesis and chlororespiration (Josse et al., 2000). PTOX is upregulated by stress in some plant species (Laureau et al., 2013)(Stepien and Johnson, 2009)(Johnson and Stepien, 2016). PTOX electron transfer to dioxygen, bypassing photosynthetic cytochrome B6f and photosystem I, may act as a safety valve for transfer of excess electrons from the photosynthetic electron transfer chain and ROS formation (Laureau et al., 2013)(Krieger-Liszkay and Feilke, 2015)(Nawrocki et al., 2015). We found clear and sustained up-regulation of PTOX gene expression in landraces B and $\mathrm{M}$ in response to drought. In this respect, cowpea resembles plants adapted to extreme environments such as the alpine plant Ranunculus glacialis or the halophyte Thellungiella halophila (Laureau et al., 2013)(Stepien and Johnson, 2009). 
Proline synthesis and catabolism genes are regulated by several stresses (Peng et al., 1996) to allow the accumulation of proline, a compatible solute with protection properties (Yoshiba et al., 1997)(Szabados and Savouré, 2010). We observed that P5CS was highly induced and ProDHI repressed in TFL1 in response to drought stress. This suggests proline was synthesised de novo in TFL1. Unexpectedly, the B landrace from a temperate climate accumulates more proline in TFL1 than the M landrace from an arid climate, suggesting that proline accumulation in TFL1 does not represent an adaptation. Although fivefold more proline accumulated in the TFL1 of landrace B, this amount of proline was still low, an estimated 30 times less than accumulates in Arabidopsis and other plant species in comparable conditions (Szabados and Savouré, 2010). Proline accumulation is known to vary between genotypes in Arabidopsis (Sharma et al., 2013)(Verslues and Sharma, 2010). In leaves of different cowpea genotypes subjected to drought stress, proline content varied from 0.77 to $3.9 \mu \mathrm{mol}$ per g of FW (Singh and Raja Reddy, 2011)(Costa et al., 2011). We found 10 to 100 times less proline in TFL1. Possibly, other studies used younger leaves or several leaves from the same plant rather than fully grown TFL1 (Singh and Raja Reddy, 2011)(Costa et al., 2011). Because levels of P5CS and PDH expression in TFL1 did not correlate with the low amount of proline found there, it is possible that another regulatory mechanism prevents proline synthesis or accumulation in TFL1. The contribution of proline accumulation to osmotic adjustment in plants is variable according to the plant species or the organ (Slama et al., 2006, Verslues and Sharma, S., 2010). However, our results suggest proline accumulation might contribute to osmotic adjustment in cowpea younger leaves.

\section{Stress perception in plant upper tier}

The RWC of the upper tier decreased during drought stress but remained higher than TFL1 RWC. This has been observed in Arabidopsis where RWC of young leaves was higher than in old leaves under drought (Sperdouli and Moustakas, 2014). Stress sensing by the upper tier of the plant was confirmed by the observed changes in expression of VuP5CS, $V u P r o D H$ and $V u D R E B 2 A$ genes. These genes were expressed prior to the onset of water stress but as RWC decreased, VuProDH gene expression was downregulated while VuP5CS and $V u D R E B 2 A$ gene expression was slightly up-regulated. Interestingly, watering plants at the end of the two-week experiment increases RWC and strongly down-regulated $V u P 5 C S$ and $V u D R E B 2 A$, showing that the apical part of the plant is sensitive to both decrease and increase in RWC. It has been shown that mobile signals including ABA and small RNA are 
associated with water-stress in cowpea (Barrera-Figueroa et al., 2011)(Shui et al., 2013). Such signals might contribute to regulating stress-related genes in distant organs.

Proline accumulation and gene expression in TFL1 and the most apical part of the shoot were regulated differently relative to RWC. Proline accumulation was 100 times higher in the upper tier compared to TFL1, suggesting either a more efficient proline synthesis or less catabolism. Younger leaves accumulate more proline than older leaves in Arabidopsis under drought stress (Sperdouli and Moustakas, 2014). In soybean after $9 \mathrm{~d}$ of drought stress, 7 times more free proline accumulates in young leaves than in older and senescent leaves (Fukutoku and Yamada, 1984). Phloem sap has also been shown to be a source of proline. Drought stressed alfalfa accumulates 60 times more proline in the sap than controls (Girousse et al., 1996), suggesting that proline is transported in the phloem from source leaves to meristematic tissues. Possibly source organs, such as TFL1, contribute to proline accumulation in young sink organs.

\section{Conclusion}

We found that two local cowpea landraces chosen from distinct geographical areas in northeast and central Algeria, respectively, respond differently to progressive simulated drought. Landrace $M$ from an arid area retained more water in adult leaves but both landraces retained water in the upper tiers of the plant during dehydration.

Stress-related genes and proline metabolism genes are regulated after the onset of stress when TFL1 RWC was still above $80 \%$. This induction of stress-related genes mirrored the down regulation of transpiration. Despite having gene expression hallmarks of increased proline biosynthesis in TFL1, only a small amount of proline accumulated in TFL1 but large amounts accumulated in the upper tier. Proline accumulation is therefore regulated between source and sink organs in the whole plant similarly in both landraces.

\section{Acknowledgements}

The authors thank Patrick Dumont (Université Pierre et Marie Curie, UPMC) for help growing cowpea plants, Yvette Habricot (UPMC) for help with the transpiration studies, Regis Maldiney (UPMC) for help with molecular biology, Yves Jolivet and Yuri Maia (Université de Lorraine) for primer sequences and Emendo Bioscience editing services (info@emendo.ac.uk) for revising the manuscript.

\section{Funding}


$\mathrm{ZZ}$ was the recipient of a grant from the Algerian Ministry of Higher Education for $\mathrm{PhD}$ training (PNE program). OA, RD, SP, CC, PC and ZZ were funded by French-Algerian exchange program Partenariat Hubert Curien Tassili 12MDU854.

\section{References}

Ba, F.S., Pasquet, R.S., Gepts, P., 2004. Genetic diversity in cowpea [Vigna unguiculata (L.) Walp.] as revealed by RAPD markers. Genet. Resour. Crop Evol. 51, 539-550. doi:10.1023/B:GRES.0000024158.83190.4e

Bac-Molenaar, J.A., Granier C., Keurentjes J.J. B. and Vreugdenhil D, 2016. Genome-Wide Association Mapping of Time-Dependent Growth Responses to Moderate Drought Stress in Arabidopsis: GWA Mapping of Growth Responses to Moderate Drought. Plant Cell Env. 39: 88-102. doi:10.1111/pce.12595.

Barrera-Figueroa, B.E., Gao, L., Diop, N.N., Wu, Z., Ehlers, J.D., Roberts, P.A., Close, T.J., Zhu, J.-K., Liu, R., 2011. Identification and comparative analysis of droughtassociated microRNAs in two cowpea genotypes. BMC Plant Biol. 11, 127. doi:10.1186/1471-2229-11-127

Bartoli, C.G., Gomez, F., Gergoff, G., Guiamét, J.J., Puntarulo, S., 2005. Up-regulation of the mitochondrial alternative oxidase pathway enhances photosynthetic electron transport under drought conditions. J. Exp. Bot. 56, 1269-1276. doi:10.1093/jxb/eri111

Bates, L.S., Waldren, R.P., Teare, I.D., 1973. Rapid determination of free proline for waterstress studies. Plant Soil 39, 205-207. doi:10.1007/BF00018060

Belko, N., Zaman-Allah, M., Diop, N.N., Cisse, N., Zombre, G., Ehlers, J.D., Vadez, V., 2013. Restriction of transpiration rate under high vapour pressure deficit and nonlimiting water conditions is important for terminal drought tolerance in cowpea. Plant Biol. Stuttg. Ger. 15, 304-316. doi:10.1111/j.1438-8677.2012.00642.x

Ben Rejeb, K., Lefebvre-De Vos, D., Le Disquet, I., Leprince, A.-S., Bordenave, M., Maldiney, R., Jdey, A., Abdelly, C., Savouré, A., 2015. Hydrogen peroxide produced by NADPH oxidases increases proline accumulation during salt or mannitol stress in Arabidopsis thaliana. New Phytol. 208, 1138-1148. doi:10.1111/nph.13550 
Bray, E.A., 2004. Genes commonly regulated by water-deficit stress in Arabidopsis thaliana. J. Exp. Bot. 55, 2331-2341. doi:10.1093/jxb/erh270

Carol, P., Kuntz, M., 2001. A plastid terminal oxidase comes to light: implications for carotenoid biosynthesis and chlororespiration. Trends Plant Sci. 6, 31-36.

Carol, P., Stevenson, D., Bisanz, C., Breitenbach, J., Sandmann, G., Mache, R., Coupland, G., Kuntz, M., 1999. Mutations in the Arabidopsis gene IMMUTANS cause a variegated phenotype by inactivating a chloroplast terminal oxidase associated with phytoene desaturation. Plant Cell 11, 57-68.

Costa, R.C.L. da, Lobato, A.K. da S., Silveira, J.A.G. da, Laughinghouse, H.D., 2011. ABAmediated proline synthesis in cowpea leaves exposed to water defi ciency and rehydration. Turk J Agric 35 309-317.

Chen, X., Laudeman, T.W., Rushton, P.J., Spraggins, T.A., Timko, M.P., 2007. CGKB: An Annotation Knowledge Base for Cowpea (Vigna Unguiculata L.) Methylation Filtered Genomic Genespace Sequences. BMC Bioinformatics 8129. doi:10.1186/1471-2105-8-129.

Costa, J.H., Jolivet, Y., Hasenfratz-Sauder, M.-P., Orellano, E.G., da Guia Silva Lima, M., Dizengremel, P., Fernandes de Melo, D., 2007. Alternative oxidase regulation in roots of Vigna unguiculata cultivars differing in drought/salt tolerance. J. Plant Physiol. 164, 718-727. doi:10.1016/j.jplph.2006.04.001

Costa, J.H., Mota, E.F., Cambursano, M.V., Lauxmann, M.A., de Oliveira, L.M.N., Silva Lima, M. da G., Orellano, E.G., Fernandes de Melo, D., 2010. Stress-induced coexpression of two alternative oxidase (VuAox1 and 2b) genes in Vigna unguiculata. J. Plant Physiol. 167, 561-570. doi:10.1016/j.jplph.2009.11.001

Cruz de Carvalho, M.H., D. Laffray, and P. Louguet. 1998. Comparison of the physiological responses of Phaseolus vulgaris and Vigna unguiculata cultivars when submitted to drought conditions. Environ. Exp. Bot. 40, 197-207.

Djebbar, R., Rzigui, T., Pétriacq, P., Mauve, C., Priault, P., Fresneau, C., De Paepe, M., Florez-Sarasa, I., Benhassaine-Kesri, G., Streb, P., Gakière, B., Cornic, G., De Paepe, R., 2012. Respiratory complex I deficiency induces drought tolerance by impacting leaf stomatal and hydraulic conductances. Planta 235, 603-614. doi:10.1007/s00425-011-1524-7

Egbadzor, K.F., Ofori, K., Yeboah, M., Aboagye, L.M., Opoku-Agyeman, M.O., Danquah, E.Y., Offei, S.K., 2014. Diversity in 113 cowpea [Vigna unguiculata (L) Walp] accessions assessed with 458 SNP markers. SpringerPlus 3, 541. doi:10.1186/2193- 
$1801-3-541$

Emberger, L., 1955. Une classification biogéographique des climats. Trav Lab Bot Zool Fac Sci Serv Montp. 7: 3-43.

Fukutoku, Y., Yamada, Y., 1984. Sources of proline-nitrogen in water-stressed soybean (Glycine max). II. Fate of 15N-labelled protein. Physiol. Plant. 61, 622-628. doi:10.1111/j.1399-3054.1984.tb05180.x

Ghalmi, N., Malice, M., Jacquemin, J.-M., Ounane, S.-M., Mekliche, L., Baudoin, J.-P., 2009. Morphological and molecular diversity within Algerian cowpea (Vigna unguiculata (L.) Walp.) landraces. Genet. Resour. Crop Evol. 57, 371-386. doi:10.1007/s10722-009-9476-5

Ghars, M.A., Richard, L., Lefebvre-De Vos, D., Leprince, A.-S., Parre, E., Bordenave, M., Abdelly, C., Savouré, A., 2012. Phospholipases C and D modulate proline accumulation in Thellungiella halophila/salsuginea differently according to the severity of salt or hyperosmotic stress. Plant Cell Physiol. 53, 183-192. doi:10.1093/pcp/pcr164

Girousse, C., Bournoville, R., Bonnemain, J.L., 1996. Water Deficit-Induced Changes in Concentrations in Proline and Some Other Amino Acids in the Phloem Sap of Alfalfa. Plant Physiol. 111, 109-113.

Hall, A.E., 2012. Phenotyping cowpeas for adaptation to drought. Front. Physiol. 3, 155. doi:10.3389/fphys.2012.00155

Hall, A., Schulze, E., 1980. Drought Effects on Transpiration and Leaf Water Status of Cowpea in Controlled Environments. Aust. J. Plant Physiol. 7, 141. doi:10.1071/PP9800141

Hayatu M., Muhammad S.Y. and Habibu U. A., 2014. Effect of water stress on the leaf relative water content and yield of some cowpea (Vigna unguiculata (L) Walp.) genotype. I. J. S. T. R. 3, 148-152.

Hodges, D. Mark, John M. DeLong, Charles F. Forney, and Robert K. Prange. 1999. Improving the Thiobarbituric Acid-Reactive-Substances Assay for Estimating Lipid Peroxidation in Plant Tissues Containing Anthocyanin and Other Interfering Compounds. Planta 207, 604-611. doi:10.1007/s004250050524.

Huynh, B.-L., Matthews, W.C., Ehlers, J.D., Lucas, M.R., Santos, J.R.P., Ndeve, A., Close, T.J., Roberts, P.A., 2016. A major QTL corresponding to the Rk locus for 
resistance to root-knot nematodes in cowpea (Vigna unguiculata L. Walp.). TAG Theor. Appl. Genet. Theor. Angew. Genet. 129, 87-95. doi:10.1007/s00122-0152611-0

Iuchi, S., Kobayashi, M., Yamaguchi-Shinozaki, K., Shinozaki, K., 2000. A stress-inducible gene for 9-cis-epoxycarotenoid dioxygenase involved in abscisic acid biosynthesis under water stress in drought-tolerant cowpea. Plant Physiol. 123, 553-562.

Iuchi, S., Yamaguchi-Shinozaki, K., Urao, T., Terao, T., Shinozaki, K., 1996. Novel drought-inducible genes in the highly drought-tolerant cowpea: cloning of cDNAs and analysis of the expression of the corresponding genes. Plant Cell Physiol. 37, 1073-1082.

Johnson, G.N., Stepien, P., 2016. Plastid Terminal Oxidase as a Route to Improving Plant Stress Tolerance: Known Knowns and Known Unknowns. Plant Cell Physiol. doi:10.1093/pcp/pcw042

Josse, E.M., Simkin, A.J., Gaffé, J., Labouré, A.M., Kuntz, M., Carol, P., 2000. A plastid terminal oxidase associated with carotenoid desaturation during chromoplast differentiation. Plant Physiol. 123, 1427-1436.

Kishor, P.B.K., Hong, Z., Miao, G. H., Hu, C.A.A., and Verma, D.P.S., 1995.

Overexpression of [delta]-Pyrroline-5-Carboxylate Synthetase Increases Proline Production and Confers Osmotolerance in Transgenic Plants. Plant Physio. 108, 1387-1394. doi:10.1104/pp.108.4.1387.

Kim, T.-H., Böhmer, M., Hu, H., Nishimura, N., Schroeder, J.I., 2010. Guard Cell Signal Transduction Network: Advances in Understanding Abscisic Acid, CO2, and Ca2+ Signaling. Annu. Rev. Plant Biol. 61, 561-591. doi:10.1146/annurev-arplant042809-112226

Kumar, A., Sharma, K. D. and Kumar, D., 2008. Traits for screening and selection of cowpea genotypes for drought tolerance at early stages of breeding. J. A. R. T. S. 109, 191-199

Krieger-Liszkay, A., Feilke, K., 2015. The Dual Role of the Plastid Terminal Oxidase PTOX: Between a Protective and a Pro-oxidant Function. Front. Plant Sci. 6, 1147. doi:10.3389/fpls.2015.01147

Laureau, C., De Paepe, R., Latouche, G., Moreno-Chacón, M., Finazzi, G., Kuntz, M., Cornic, G., Streb, P., 2013. Plastid terminal oxidase (PTOX) has the potential to act as a safety valve for excess excitation energy in the alpine plant species Ranunculus glacialis L. Plant Cell Environ. 36, 1296-1310. doi:10.1111/pce.12059 
Maia, Y. 2012. Caractérisation de la réponse de deux cultivars de Vigna unguiculata à une contrainte ozone combinée ou non à la sécheresse : Régulation de protéines membranaires (AOX, PTOX et pUCP). Thèse de l'Université de Lorraine Universidade federal do Ceará. http://www.theses.fr/2012LORR0258/document.

Mckay, J. K., Richards J. H. and Mitchell-Olds T., 2003. Genetics of Drought Adaptation in Arabidopsis Thaliana: I. Pleiotropy Contributes to Genetic Correlations among Ecological Traits. Molecular Ecology 12, 1137-51. doi:10.1046/j.1365294X.2003.01833.x.

Mittler, R., 2002. Oxidative stress, antioxidants and stress tolerance. Trends Plant Sci. 7, 405-410.

Muchero, W., Ehlers, J.D., Close, T.J., Roberts, P.A., 2009. Mapping QTL for drought stress-induced premature senescence and maturity in cowpea [Vigna unguiculata (L.) Walp.]. TAG Theor. Appl. Genet. Theor. Angew. Genet. 118, 849-863. doi:10.1007/s00122-008-0944-7

Muchero, W., Ehlers, J.D., Roberts, P.A., 2010. Restriction site polymorphism-based candidate gene mapping for seedling drought tolerance in cowpea [Vigna unguiculata (L.) Walp.]. TAG Theor. Appl. Genet. Theor. Angew. Genet. 120, 509-518. doi:10.1007/s00122-009-1171-6

Nawrocki, W.J., Tourasse, N.J., Taly, A., Rappaport, F., Wollman, F.-A., 2015. The plastid terminal oxidase: its elusive function points to multiple contributions to plastid physiology. Annu. Rev. Plant Biol. 66, 49-74. doi:10.1146/annurev-arplant043014-114744

Osonubi, O., 1985. Responses of Cowpeas (Vigna unguiculata (L.) Walp.) to Progressive Soil Drought. Oecologia 66, 554-557.

Pasquet, R.S., 1999. Genetic relationships among subspecies of Vigna unguiculata (L.) Walp. based on allozyme variation. Theor. Appl. Genet. 98, 1104-1119. doi: $10.1007 / \mathrm{s} 001220051174$

Pasquet, R.S., 1993. Variation at isozyme loci in wild Vigna Unguiculata (Fabaceae, Phaseoleae). Pl Syst Evol 157- 173.

Peel, M.C., Finlayson, B.L., McMahon, T.A., 2007. Updated world map of the KöppenGeiger climate classification. Hydrol Earth Syst Sci 11, 1633-1644. doi:10.5194/hess-11-1633-2007

Peng, Z., Lu, Q., Verma, D.P., 1996. Reciprocal regulation of delta 1-pyrroline-5carboxylate synthetase and proline dehydrogenase genes controls proline levels 
during and after osmotic stress in plants. Mol. Gen. Genet. MGG 253, 334-341.

Pérez-Arellano, I., Carmona-Álvarez, F., Martínez, A.I., Rodríguez-Díaz, J., Cervera, J., 2010. Pyrroline-5-carboxylate synthase and proline biosynthesis: From osmotolerance to rare metabolic disease. Protein Sci. Publ. Protein Soc. 19, 372382. doi:10.1002/pro.340

Rosales, M.A, Cuellar-Ortiz, S.M, Arrieta-Montiel M.P., Acosta-Gallegos, J. Covarrubias, A.A., 2011. Physiological Traits Related to Terminal Drought Resistance in Common Bean ( Phaseolus Vulgaris L.): Drought Resistance-Related Traits in Common Bean. J. Sci. Food Agr. 93, 324-331. doi:10.1002/jsfa.5761.

Sadhukhan, A., Kobayashi, Y., Kobayashi, Y., Tokizawa, M., Yamamoto, Y.Y., Iuchi, S., Koyama, H., Panda, S.K., Sahoo, L., 2014a. VuDREB2A, a novel DREB2-type transcription factor in the drought-tolerant legume cowpea, mediates DREdependent expression of stress-responsive genes and confers enhanced drought resistance in transgenic Arabidopsis. Planta 240, 645-664. doi:10.1007/s00425$014-2111-5$

Sadhukhan, A., Panda, S.K., Sahoo, L., 2014b. The cowpea RING ubiquitin ligase VuDRIP interacts with transcription factor VuDREB2A for regulating abiotic stress responses. Plant Physiol. Biochem. 83, 51-56. doi:10.1016/j.plaphy.2014.07.007

Savouré, A., Hua, X.J., Bertauche, N., Van Montagu, M., Verbruggen, N., 1997. Abscisic acid-independent and abscisic acid-dependent regulation of proline biosynthesis following cold and osmotic stresses in Arabidopsis thaliana. Mol. Gen. Genet. MGG 254, 104-109.

Sharma, S., Lin, W., Villamor, J.G., Verslues, P.E., 2013. Divergent low water potential response in Arabidopsis thaliana accessions Landsberg erecta and Shahdara. Plant Cell Environ. 36, 994-1008. doi:10.1111/pce.12032

Shinozaki, K., Yamaguchi-Shinozaki, K., 1997. Gene Expression and Signal Transduction in Water-Stress Response. Plant Physiol. 115, 327-334.

Shui, X.R., Chen Z.W. and Li J.X., 2013. MicroRNA prediction and its function in regulating drought-related genes in cowpea. Plant Sci. 210, 25-35. doi:10.1016/j.plantsci.2013.05.002.

Singh, S.K., Kakani, V.G., Surabhi, G.-K., Reddy, K.R., 2010. Cowpea (Vigna unguiculata [L.] Walp.) genotypes response to multiple abiotic stresses. J. Photochem. Photobiol. B 100, 135-146. doi:10.1016/j.jphotobiol.2010.05.013

Singh, S.K., Raja Reddy, K., 2011. Regulation of photosynthesis, fluorescence, stomatal 
conductance and water-use efficiency of cowpea (Vigna unguiculata [L.] Walp.) under drought. J. Photochem. Photobiol. B 105, 40-50. doi:10.1016/j.jphotobiol.2011.07.001

Slama I, Messedi D, Ghnaya T, Savoure A, Abdelly . (2006) Effects of water deficit on growth and proline metabolism in Sesuvium portulacastrum Environmental and Experimental Botany 56, 231-238

Sperdouli, I., Moustakas, M., 2014. Leaf developmental stage modulates metabolite accumulation and photosynthesis contributing to acclimation of Arabidopsis thaliana to water deficit. J. Plant Res. 127, 481-489. doi:10.1007/s10265-0140635-1

Stepien, P., Johnson, G.N., 2009. Contrasting responses of photosynthesis to salt stress in the glycophyte Arabidopsis and the halophyte thellungiella: role of the plastid terminal oxidase as an alternative electron sink. Plant Physiol. 149, 1154-1165. doi:10.1104/pp.108.132407

Strizhov, N., Abrahám, E., Okrész, L., Blickling, S., Zilberstein, A., Schell, J., Koncz, C., Szabados, L., 1997. Differential expression of two P5CS genes controlling proline accumulation during salt-stress requires $\mathrm{ABA}$ and is regulated by $\mathrm{ABA} 1, \mathrm{ABI} 1$ and AXR2 in Arabidopsis. Plant J. Cell Mol. Biol. 12, 557-569.

Szabados, L., Savouré, A., 2010. Proline: a multifunctional amino acid. Trends Plant Sci. 15, 89-97. doi:10.1016/j.tplants.2009.11.009

Todd, J.J., Vodkin, L.O., 1996. Duplications That Suppress and Deletions That Restore Expression from a Chalcone Synthase Multigene Family. Plant Cell 8, 687-699. doi:10.1105/tpc.8.4.687

Torres-Franklin, M.L., Contour-Ansel, D., Zuily-Fodil, Y., Pham-Thi, A.-T., 2008. Molecular cloning of glutathione reductase cDNAs and analysis of GR gene expression in cowpea and common bean leaves during recovery from moderate drought stress. J. Plant Physiol. 165, 514-521. doi:10.1016/j.jplph.2007.03.011

Torres-Franklin, M.-L., Gigon, A., de Melo, D.F., Zuily-Fodil, Y., Pham-Thi, A.-T., 2007. Drought stress and rehydration affect the balance between MGDG and DGDG synthesis in cowpea leaves. Physiol. Plant. 131, 201-210. doi:10.1111/j.13993054.2007.00943.x

Tuteja, J.H., Zabala, G., Varala, K., Hudson, M., Vodkin, L.O., 2009. Endogenous, TissueSpecific Short Interfering RNAs Silence the Chalcone Synthase Gene Family in Glycine max Seed Coats. Plant Cell 21, 3063-3077. doi:10.1105/tpc.109.069856 
Umbach, A.L., Ng, V.S., Siedow, J.N., 2006. Regulation of plant alternative oxidase activity: A tale of two cysteines. Biochim. Biophys. Acta BBA - Bioenerg. 1757, 135-142. doi:10.1016/j.bbabio.2005.12.005

Vanlerberghe, G.C., Martyn, G.D., Dahal, K., 2016. Alternative oxidase: a respiratory electron transport chain pathway essential for maintaining photosynthetic performance during drought stress. Physiol. Plant. 157, 322-337. doi:10.1111/ppl.12451

Verslues, P.E., Sharma, S., 2010. Proline Metabolism and Its Implications for PlantEnvironment Interaction. Arab. Book Am. Soc. Plant Biol. 8. doi:10.1199/tab.0140

Wang, J., Vanlerberghe, G.C., 2013. A lack of mitochondrial alternative oxidase compromises capacity to recover from severe drought stress. Physiol. Plant. doi:10.1111/ppl.12059

Xu, P., Moshelion, M., Wu, X., Halperin, O., Wang, B., Luo, J., Wallach, R., Wu, X., Lu, Z., Li, G., 2015. Natural variation and gene regulatory basis for the responses of asparagus beans to soil drought. Front. Plant Sci. 6, 891. doi:10.3389/fpls.2015.00891

Yoshiba, Y., Kiyosue, T., Nakashima, K., Yamaguchi-Shinozaki, K., Shinozaki, K., 1997. Regulation of levels of proline as an osmolyte in plants under water stress. Plant Cell Physiol. 38, 1095-1102 
Figure 1. Decrease in relative water content in cowpea landraces.

A

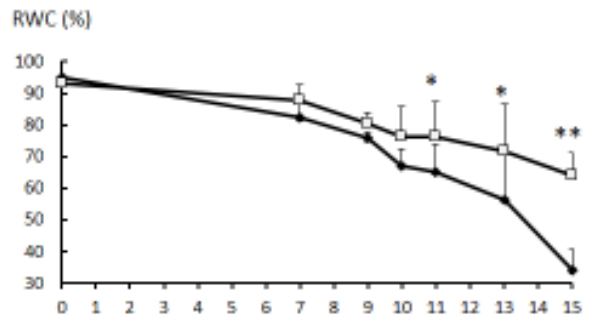

Days

B

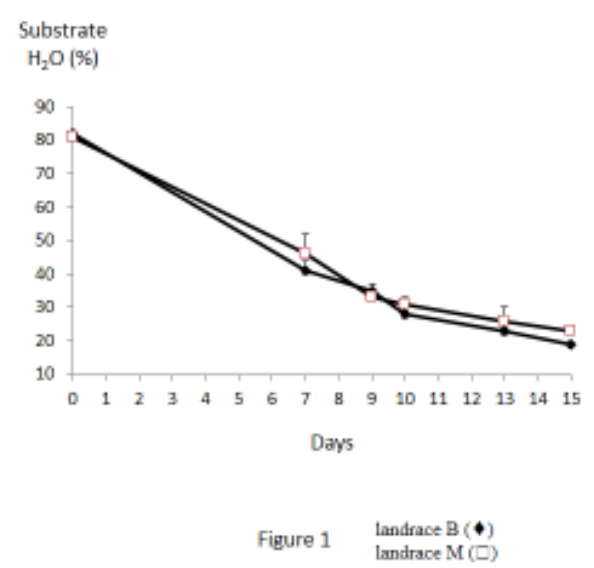

A, Relative water content (RWC) of first trifoliate leaves and B, soil humidity during water deprivation of landrace B $(\bullet)$ and landrace $\mathrm{M}(\square)$. Measurements were done daily after soil was watered to saturation on Day 0. Significant differences between landraces $(n=8)$ are indicated by $*$ for $\mathrm{p}<0.05$ and $* *$ for $\mathrm{p}<0.01$ in Mann-Whitney tests. Error bars represent standard deviation. 
Figure 2. Leaf transpiration rates decrease during water deprivation.

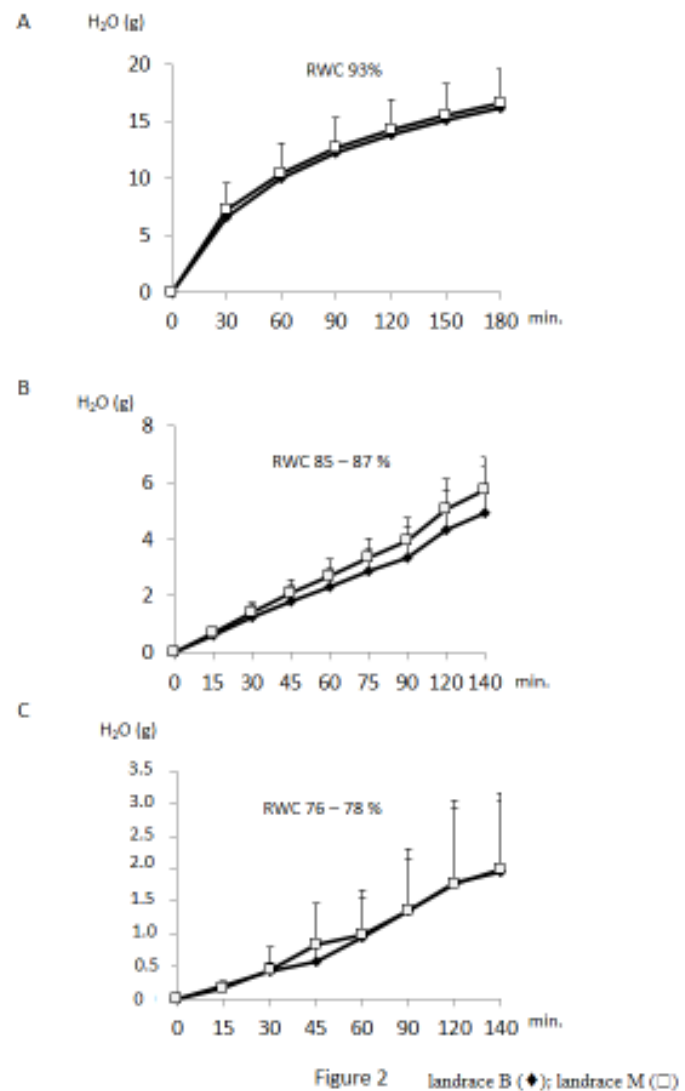

The amount of water transpired by detached TFL1 of landrace B ( $\bullet$ ) and landrace M ( $\square$ ) was recorded over 2-3 hours and results are given as a percentage of the initial leaf RWC of A, $93 \%, \mathrm{~B}, 85-87 \%$ and $\mathrm{C}, 76-78 \%$. Transpiration rates were significantly different at $\mathrm{p}<$ 0.01 in Mann-Whitney tests between the three RWC categories, but there was no difference between landraces at the same RWC. Error bars represent standard deviation. 
Figure 3. Whole plant transpiration rates decrease during water deprivation.

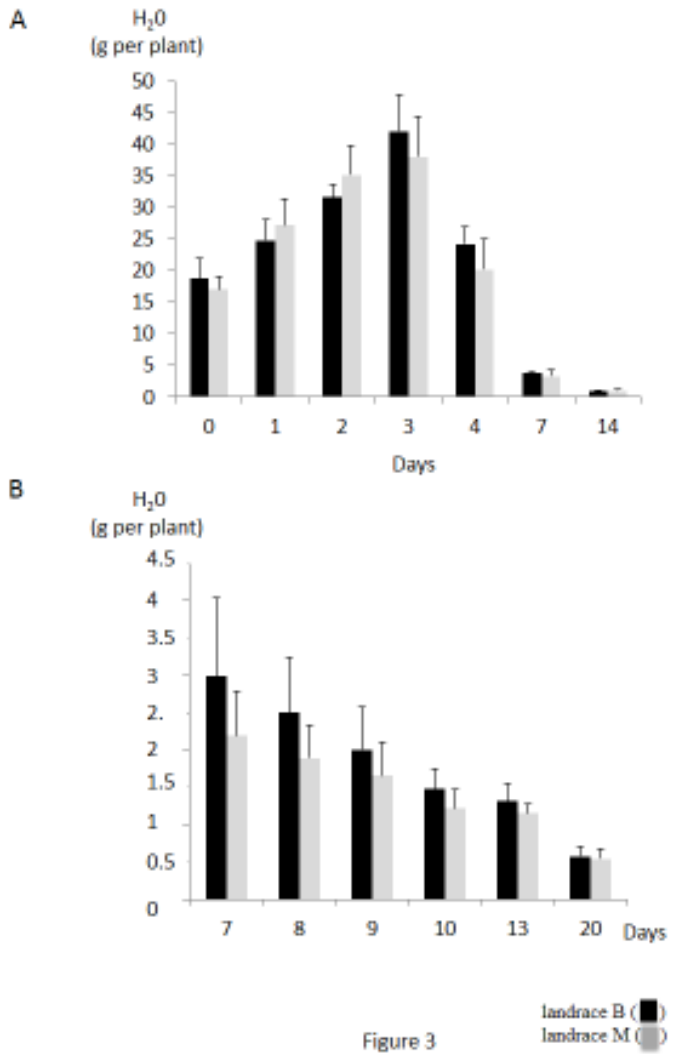

A, Water loss from whole plants was recorded daily for the first week of water deprivation and again after 2 weeks. B, Water loss recorded between 7 and 20 days after the start of water deprivation. Differences between landrace B (black bars) and landrace M (grey bars) were found consistently but are only moderately significant ( $n=9$ plants, $p=0.07$ in MannWhitney test). 
Figure 4. Stress-related and proline-metabolism gene expression and proline content in TFL1.

A

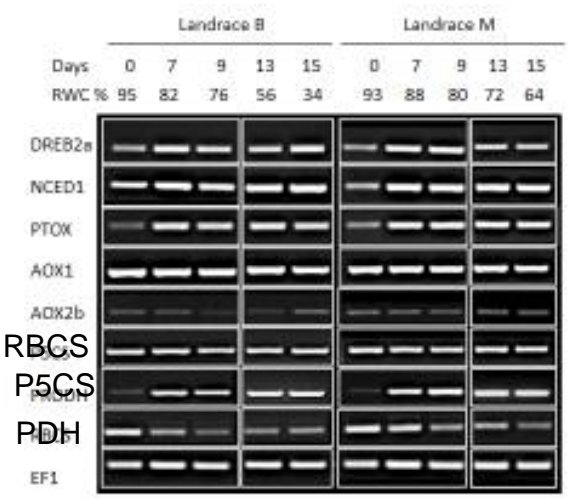

B Proline

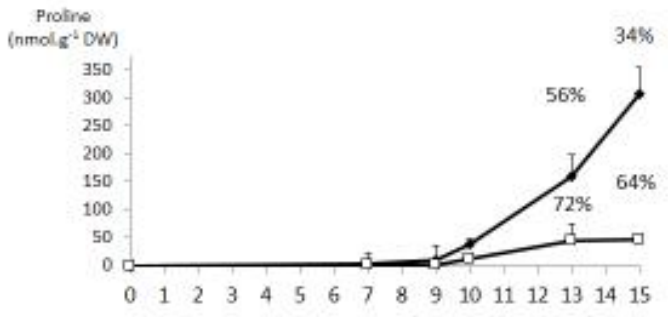

Finure 4 landrace $B(\bullet)$

Number of days after the start of water deprivation and RWC values measured at the time of tissue harvest are indicated. A, RT-PCR was used to test gene expression levels in cowpea landraces using semi-quantitative conditions that reveal differences in the amounts of template molecules without saturation of the amplification reaction. EF1, gene encoding EF1alpha, whose expression is constant, was used as a reference. Details of enzyme activities and biological roles are given in the main text and details of gene and primer sequences are given in Table 2. B, Proline content in TFL1 of landrace B (•) and landrace M ( $\square$ ) following water deprivation. The values above each curve indicate the corresponding RWC. Differences in proline content between landraces $(n=4)$ are significant after 13 and 15 days with $\mathrm{p}<0.01$ in a Mann-Whitney test. 
Figure 5. Proline-metabolism gene expression and proline content in upper tiers of cowpea plants during water stress.
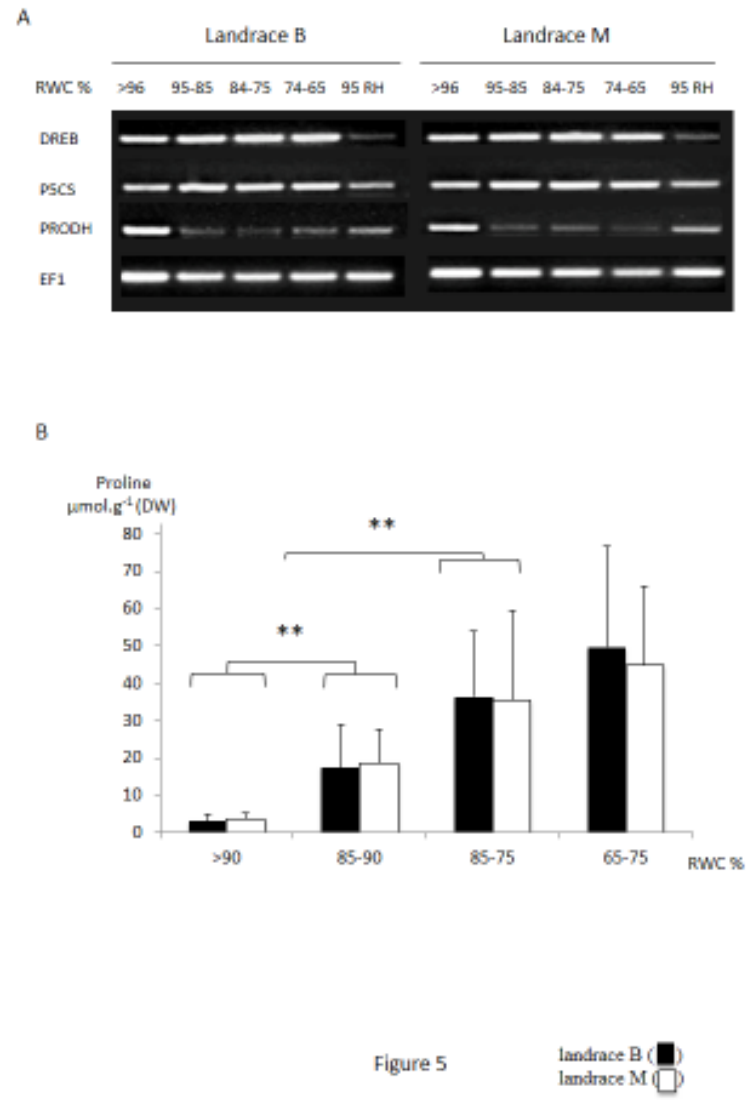

A, RT-PCR was used to test gene expression levels in upper tiers of cowpea landraces using semi-quantitative conditions that reveal differences in the amounts of template molecules without saturation of the amplification reaction. EF1, gene encoding EF1alpha, whose expression is constant, was used as a reference, Details of enzyme activities and biological roles are given in the main text and details of gene and primer sequences are given in Table 2. The percentage values below indicate the corresponding RWC during water deprivation, while $95 \mathrm{RH}$ indicates samples that were watered at the end of dehydration period. B, Proline content in upper tiers of landrace B (black bars) and landrace M (clear bars) deprived of water. RWC values of tissues at the time of harvest are indicated. **, significant differences between samples $(n=6)$ at $p<0.01$ in Mann-Whitney test. 
Table 1: Characteristics of geographical origin of cowpea landraces used in this study. $T^{\circ}$ : temperature.

\begin{tabular}{|c||c|c|}
\hline \multicolumn{1}{|c||}{ Landrace } & Bejaia (B) & Menia (M) \\
\hline Area of origin & Bejaia (North-East Algeria) & Menia (Central Algeria) \\
\hline Geographical location & $36^{\circ} 45^{\prime} \mathrm{N}, 5^{\circ} 05^{\prime} \mathrm{E}$ & $30^{\circ} 35^{\prime} \mathrm{N}, 2^{\circ} 51^{\prime} \mathrm{E}$ \\
\hline Elevation above sea level & $86 \mathrm{~m}$ & $387 \mathrm{~m}$ \\
\hline $\begin{array}{c}\text { Climate (Emberger) } \\
\text { (Emberger, 1955) }\end{array}$ & Sub humid & Hot arid \\
\hline $\begin{array}{c}\text { Climate (Köppen-Geiger) } \\
\text { (Peel et al., 2007) }\end{array}$ & Csa & $31.9^{\circ} \mathrm{C}$ \\
\hline Average Temperature & $17.6^{\circ} \mathrm{C}$ & $34 \mathrm{~mm}$ \\
\hline Annual Rainfall & $834 \mathrm{~mm}$ & \\
\hline
\end{tabular}


Table 2: Oligonucleotide DNA primers used in this study

\begin{tabular}{|c|c|c|c|}
\hline Gene & Primer $\mathrm{F}$ & Primer $\mathrm{R}$ & $\begin{array}{l}\text { Sequence name, Genebank and } \\
\text { publication }\end{array}$ \\
\hline AOX1 & AAGATGGAGAAGAAGGTTGGT & TGTATGTCTCCCATGGCCTA & Costa et al., 2010 \\
\hline AOX2B & CTTCAAGGAACGGTATGGG & AGAGTGCTGAAACTTCCTC & $\begin{array}{l}\text { (Genbank AJ421015) } \\
\text { Costa et al., } 2010\end{array}$ \\
\hline PTOX & TCCAAATCATCTCCACTTCAC & CTTTATCACAGAATCCGTGAG & Maia, 2012 \\
\hline P5CS & TAACTCACCTCAACTCGCTC & AACAGCACCTGAAGTTACCA & VuP5CS (Genbank AB056452.2) \\
\hline PDH & ATGCTCGAGAAGATTGCTGA & ACAGGTCCAAATGGCATGTA & $\begin{array}{l}\text { VuProdh (Genbank AB779665) } \\
\text { Kaneko et al., } 2013\end{array}$ \\
\hline DREB2A & AAGCTGCTCTTGCCTATGAT & CTGCTAGTTGGTGAGGCATA & $\begin{array}{l}\text { VuDREB2A (Genbank JN629045.3) } \\
\text { Sadhukhan et al., } 2014\end{array}$ \\
\hline NCED1 & GATGCACGATTTCGCCATAA & GGTGGAAGCAGAAACAATCC & $\begin{array}{l}\text { VuCPRD65 VuNCED1 (AB030293.1) } \\
\text { neoxanthine cleavage system } \\
\text { Iuchi et al., } 2000\end{array}$ \\
\hline EF1a & GTAACAAGATGGATGCCACC & CCACTTTCTTCAAATACGAGGAG & Maia, 2012 \\
\hline RBCS & CATACCGTGAGCAAAACAGG & GGCAATGAAACTGATGCACT & VuRBCS (Genbank JN692253.2) \\
\hline
\end{tabular}

